\title{
Asymptomatic bacteriuria in antenatal cases and its effects on obstetrical outcome
}

\author{
Ridhi Narang, Gurpreet K. Nandmer*
} Department of Obstetrics and Gynecology, Peoples College of Medical Sciences and Research Centre, Bhopal,
Madhya Pradesh, India

Received: 27 January 2019

Accepted: 15 February 2019

*Correspondence:

Dr. Gurpreet K. Nandmer,

E-mail: kaurgauri2@yahoo.co.in

Copyright: () the author(s), publisher and licensee Medip Academy. This is an open-access article distributed under the terms of the Creative Commons Attribution Non-Commercial License, which permits unrestricted non-commercial use, distribution, and reproduction in any medium, provided the original work is properly cited.

\begin{abstract}
Background: Urinary tract infection is the second most common bacterial infection seen during pregnancy and is due to the morphological and physiological changes that take place in the genitourinary tract. The pregnant women are two times more commonly affected than age matched non pregnant females and it may lead to less favorable pregnancy outcomes and complications such as premature birth, low birth weight, pyelonephritis, preeclampsia and anemia.

Methods: This hospital based cross sectional study was conducted on 350 pregnant women, falling into the inclusion criteria of the study, who attended the antenatal clinic in the Department of Obstetrics and Gynecology at PCMS and $\mathrm{RC}$, Bhopal, irrespective of the gestational age of the cases. The cases found to have asymptomatic bacteriuria were followed till delivery and any adverse antenatal or perinatal outcome was noted.

Results: The study was conducted with the aim to know the prevalence of asymptomatic bacteriuria and the obstetrical outcome in pregnant women. The prevalence of asymptomatic bacteriuria was $13 \%$ and it was common in the age group of 21-25 years, in primigravidas and with period of gestation less than 12 weeks. E. coli was found to be the commonest causative organism. Asymptomatic bacteriuria was found significantly associated with the presence of anemia. Maternal morbidity in terms of pre term labour was higher in cases with asymptomatic bacteriuria.

Conclusions: Urine culture and sensitivity should be done as a routine investigation to screen the patients for asymptomatic bacteriuria and to prevent adverse maternal and fetal outcomes.
\end{abstract}

Keywords: Asymptomatic bacteriuria, Obstetrical outcome, Urine culture and sensitivity

\section{INTRODUCTION}

Urinary tract infection is one of the most frequent bacterial infection. ${ }^{1}$ It is the second most common bacterial infection seen during pregnancy. ${ }^{2}$ due to the morphological and physiological changes that takes place in the genitourinary tract. The pregnant women are two times more commonly affected than age matched non pregnant females. ${ }^{3,4}$ UTI in the pregnant women begins in the $6^{\text {th }}$ week and reaches its peak in weeks 22-24. It is of two types, symptomatic or asymptomatic. ${ }^{5}$ Symptomatic bacteriuria is the tip of an iceberg and easy to diagnose due to its overt symptoms, but asymptomatic bacteriuria is difficult. ${ }^{6}$ Asymptomatic bacteriuria (ASB) is defined as the "presence of actively and persistently multiplying bacteria within the urinary tract excluding the distal urethra", at a time when the patient has no urinary symptoms or defined as the presence of bacteria in a significant number i.e., $1 \times 10^{5}$ colony forming unit (CFU) per $\mathrm{ml}$ in a culture of clean voided midstream urine from an antenatal women without fever or symptoms of UTI. ${ }^{7}$

The prevalence in pregnancy varies from 2 to $12 \%$ and it depends on parity, race, and socioeconomic status. ${ }^{7}$ 
Stenqvist and colleagues have shown that 18 weeks of gestation is the optimal time for performing screening culture for detecting bacteriuria. ${ }^{8}$ After anemia, UTIs are the second most common complication in pregnant women, which can adversely affect the health of infant or the pregnant mother and may lead to less favorable pregnancy outcomes and complications such as premature birth, low birth weight, still birth and pyelonephritis. $^{9,10}$ Urine culture is the gold standard screening technique for ASB during pregnancy. ${ }^{11-13}$ Screening of asymptomatic subjects for bacteriuria is appropriate as bacteriuria has adverse outcomes that can be prevented by antimicrobial therapy.

If asymptomatic bacteriuria is not treated, approximately $25 \%$ of women will subsequently develop acute symptoms of an infection during pregnancy, hypertension in pregnant women, postpartum UTI, anaemia, preterm labour, low birth weight and perinatal death of the fetus. ${ }^{14}$ Asymptomatic bacteriuria (ASB) is an entity with possibly serious consequences in the form of fetal and maternal morbidity. ${ }^{15}$ The most common infecting organism is Escherichia coli, which is responsible for 75$90 \%$ of bacteriuria during pregnancy. $25-30 \%$ of the asymptomatic bacteriuria cases develop into acute symptomatic UTI. Hence, early detection and treatment is of considerable importance not only to prevent acute pyelonephritis and chronic renal failure in the mother, but also to reduce prematurity and fetal mortality. ${ }^{6}$

\section{METHODS}

A hospital based cross sectional study was carried out in the department of obstetrics and gynecology at Peoples College of Medical Sciences, Hospital and Research Centre, Bhopal. This study was done with the approval of the institutional ethical committee for 18 months from August 2014 to February 2016. Antenatal patients, irrespective of the gestational age, who fell into the inclusion criteria were registered in antenatal clinic. Details of the study protocol was explained to the subjects and informed consent was obtained.

\section{Inclusion criteria}

- Willing to participate in the study.

- Antenatal cases attending antenatal clinic at PCMS and RC.

- Pregnant women who have no symptoms and signs of UTI like pyrexia, dysuria, frequency and urgency.

- Pregnant women who were not on any antibiotics for last 14 days.

- Pregnant women who do not have any medical disorder like diabetes, pregnancy induced hypertension or renal disease.

\section{Exclusion criteria}

- Patient not willing to participate in the study.
- Pregnant women who have clinical signs and symptoms of UTI like pyrexia, dysuria, frequency and urgency.

- Pregnant women who were on any antibiotic treatment within last 14 days of sample collection.

- Pregnant women who have medical illness like pregnancy induced hypertension, history of fever.

A detailed history including history of previous urinary tract infection, obstetric, menstrual and medical histories were taken. General physical examination, systemic examination, per-abdominal examination was done, and basic routine antenatal investigations were sent for all patients including preliminary hemoglobin estimation, urine-albumin and sugar, random blood sugar, blood urea, urine routine examination and urine culture and sensitivity. With the collected urine samples, before proceeding to culture, microscopic and chemical examination of urine was done. All pregnant women were first instructed, how to collect mid- stream urine specimen. The specimens were collected in the outpatient clinic of the hospital in 2 separate sterile wide mouthed containers with lid. The containers were immediately processed within 1-2 hours.

Various variables were studied:

- Age

- Literacy

- Socio-economic status

- Gravida

- Parity

- Period of gestation

- Previous history of urinary tract infection

- Anemia

- Pre term labour (onset of labour before 37 weeks)

- Urine for albumin.

Patients with significant asymptomatic bacteriuria were treated and followed up till delivery. Maternal outcomes like anemia and preterm labour were studied and analysed.

\section{Statistical analysis}

The data was analyzed using chi square and proportions were calculated by using statistical software SPSS 16.0 version and $\mathrm{p}$ value less than 0.05 was considered as statistically significant.

\section{RESULTS}

A total of 350 cases participated in the study of which 45 were positive for bacteria on culture and 305 were negative, contributing to a prevalence of $13 \%$. $60 \%$ (27) of ASB was seen in age group of 21-25 years, followed by $29 \%$ (13) in 26-30 years. ASB was least common $4 \%$ (2) in age group 15-20 years. Culture was negative for 
cases above 35 years of age. No significant association was found in relation to age (Table 1).

Table 1: Association of asymptomatic bacteriuria with age distribution.

\begin{tabular}{|l|l|l|l|}
\hline Age (years) & Negative & Positive & Total \\
\cline { 2 - 3 } & $\mathbf{N}$ & $\mathbf{N}$ & $\mathbf{N}$ \\
\hline $15-20$ & $28(9 \%)$ & $2(4 \%)$ & $30(9 \%)$ \\
\hline 21 to 25 & $167(5 \%)$ & $27(60 \%)$ & $194(55 \%)$ \\
\hline 26 to 30 & $76(25 \%)$ & $13(29 \%)$ & $89(25 \%)$ \\
\hline $31-35$ & $28(9 \%)$ & $3(7 \%)$ & $31(9 \%)$ \\
\hline 36 to 40 & $6(2 \%)$ & $0(0 \%)$ & $6(2 \%)$ \\
\hline Total & 305 & 45 & 350 \\
\hline
\end{tabular}

$\chi^{2}=2.629, \mathrm{p}=0.6222$

$31 \%$ (14) of cases with ASB were from period of gestation < 12 weeks followed by $29 \%$ (13) from 13-20 weeks. ASB was seen equally in 29-40 weeks and $>40$ weeks gestation i.e. $11 \%$ (5). No significant relation was found (Table 2).

Table 2: Association of asymptomatic bacteriuria with period of gestation.

\begin{tabular}{|l|l|l|l|}
\hline $\begin{array}{l}\text { Period of } \\
\text { gestation }\end{array}$ & Negative & Positive & Total \\
\hline Less than 12 & $89(29 \%)$ & $\mathbf{N}$ & $\mathbf{N}$ \\
\hline $13-20$ & $85(28 \%)$ & $13(29 \%)$ & $103(29 \%)$ \\
\hline $21-28$ & $48(16 \%)$ & $8(18 \%)$ & $56(28 \%)$ \\
\hline $29-40$ & $63(21 \%)$ & $5(11 \%)$ & $68(19 \%)$ \\
\hline More than 40 & $20(7 \%)$ & $5(11 \%)$ & $25(7 \%)$ \\
\hline Total & 305 & 45 & 350 \\
\hline
\end{tabular}

$\chi^{2}=3.143, \mathrm{p}=0.534$

$60 \%$ (27) of primigravidae patients had ASB followed by $38 \%$ (17) of multigravida but there was no significant relation found with parity.

Commonest organism detected was E. coli with an incidence of $51 \%$ (23) followed by Staphylococcus aureus 15\% (7), Klebsiella pneumonia 13\% (6) and enterobacter $9 \%$ (4). Acinetobacter and Candida albicans were seen only in $7 \%$ (3) and $2 \%$ (1) respectively (Table 3).

Table 3: Distribution of causative organisms in patients with asymptomatic bacteriuria.

\begin{tabular}{|l|l|}
\hline Type of bacteria & N \\
\hline Acinetobacter & $3(7 \%)$ \\
\hline Candida albicans & $1(2 \%)$ \\
\hline E. coli & $23(51 \%)$ \\
\hline Enterobacter & $4(9 \%)$ \\
\hline Klebsiella pneumonia & $6(13 \%)$ \\
\hline Multiple bacteria & $1(2 \%)$ \\
\hline Staphylococcus aureus & $7(15 \%)$ \\
\hline Total & 45 \\
\hline$\chi 2=1.606, \mathrm{p}=0.448$ & \\
\hline
\end{tabular}

$\chi^{2}=1.606, \mathrm{p}=0.448$
Out of 350 cases, $7 \%$ (24) had pre term labour. ASB was significantly associated with pre term labour with (Table 4).

Table 4: Association of asymptomatic bacteriuria with pre term labor.

\begin{tabular}{|c|c|c|c|}
\hline & \multirow{2}{*}{$\begin{array}{l}\text { ASB } \\
\mathbf{N}\end{array}$} & \multirow{2}{*}{$\begin{array}{l}\text { Sterile } \\
\mathbf{N}\end{array}$} & \multirow{2}{*}{ Total } \\
\hline & & & \\
\hline $\begin{array}{l}\text { Pre term } \\
\text { labor } \\
\text { Yes }\end{array}$ & $16(36 \%)$ & $8(3 \%)$ & $24(7 \%)$ \\
\hline No & $29(64 \%)$ & $297(97 \%)$ & $326(93 \%)$ \\
\hline Total & 45 & 305 & 350 \\
\hline
\end{tabular}

The samples were analyzed for associated medical disorders like diabetes, anemia. No cases were associated with any medical disorder except anemia. The severity of anemia was also predicted and its association with ASB. ASB was more common in cases with anemia and it was found significant with $\chi 2=28.059, \mathrm{p}=0.000$ (Table 5).

Table 5: Association of asymptomatic bacteriuria with severity of anemia.

\begin{tabular}{|l|l|l|l|}
\hline Hb & Negative & Positive & Total \\
\hline No anemia & N & N & N \\
\hline Moderate anemia & $187(61 \%)$ & $12(27 \%)$ & $199(57 \%)$ \\
\hline Severe anemia & $20(7 \%)$ & $21(47 \%)$ & $119(34 \%)$ \\
\hline Total & 305 & $12(26 \%)$ & $32(9 \%)$ \\
\hline
\end{tabular}

\section{DISCUSSION}

In present study, the prevalence of asymptomatic bacteriuria in antenatal women was found to be $13 \%$. The prevalence of asymptomatic bacteriuria in antenatal cases has been documented to be as high as $30-50 \%$ to as low as $5-7 \%$, it was reported as $11 \%$ in a study by Chukwu et al, Kasinathan A et al, reported significant bacteriuria in $12.6 \%$ cases. $^{16,17}$

In the study by Lallar et al prevalence was on higher side that is $16 \%$. There was not much difference in the prevalence of ASB in present study as compare to the previous studies. ${ }^{18}$

As regards with age, ASB was most commonly (60\%) observed in age group of 21-25 years followed by $29 \%$ in age group 26-30 years and the least cases $4.4 \%$ were seen in younger generation of age group 15-20 years with less reproductive life span.

However, the results were in contrary to the studies by Kerure et al that showed the highest number of culture positive cases in the age group of 26-35 years $(52 \%)$ and by Chukwu et al in 2014 noticed in age bracket of 36-40 years $(25 \%) .{ }^{16,19}$

E. coli was the common organism detected in $51 \%$ cases followed by Staphylococcus aureus in $16 \%$ cases, 
Klebsiella pneumonia $13 \%$ and enterobacter $9 \%$. Acinetobacter and Candida albicans were seen only in $7 \%$ and $2 \%$ respectively. E. coli was found to be the predominant organism in other studies conducted by Chukwu, Kerure, Lallar. ${ }^{16,18,19}$ However, the results were in contrary to the study by Tadesse et al where the predominant bacterial species were coagulase negative Staphylococcus followed by E. coli. ${ }^{20}$

Asymptomatic bacteriuria was more common in primigravidae cases. This observation is probably because the maximum number of participants were primigravidas. Kerure et al also documented significant bacteriuria in primigravida as $56 \% .{ }^{19}$ However, results reported by Chukwu et al and Lallar et al were contrary to present study, they found the highest incidence in women with four pregnancies. ${ }^{16,18}$

Asymptomatic bacteriuria was most common observation in first $(31 \%)$ and early second trimester $(29 \%)$ which is similar to the study done by Chukwu et al in 2014. ${ }^{16}$ However, the results by Kerure et al showed that the ASB was commonly seen in second trimester (44.4\%) followed by first $(28.8 \%) .{ }^{19}$

ASB was seen in $47 \%$ of patients with anemia (47\%) and the results were statistically significant with $p$ value $<0.05$. Lallar et al and Ansari HQ et al also found significant association of ABU with anemia. ${ }^{18,21}$

In present study, ASB was significantly associated with pre term labour with $\mathrm{p}$ value $<0.05$, results were similar to the study by Vaishali et al and Asopa J et al (29\%). ${ }^{22,23}$ Albuminuria and presence of bacteria in urine was also significantly associated with $\mathrm{p}$ value $<0.05$.

\section{CONCLUSION}

Asymptomatic bacteriuria is a common urinary tract infection in pregnant cases. Pregnant women with asymptomatic bacteriuria are at an increased risk to adverse maternal and fetal outcomes, which can be prevented by antimicrobial treatment of asymptomatic bacteriuria during antenatal period and because of its high prevalence in pregnancy, it is imperative that pregnant women should be screened for ASB, especially in their first trimester. Urine culture tests should be carried out for all the pregnant women and they should be treated as per the sensitivity reports to prevent adverse outcomes associated with pregnancy like pre term labour.

Urine culture is the effective method to screen ASB and should be incorporated as routine antenatal care investigation for safe motherhood.

\section{Funding: No funding sources} Conflict of interest: None declared

Ethical approval: The study was approved by the Institutional Ethics Committee

\section{REFERENCES}

1. Stamm WE, Hooton TM. Management of urinary tract infections in adults. $\mathrm{N}$ Engl $\mathrm{J}$ Med. 1993;329:1328-34.

2. Sampson JE, Gravett MG, Other infectious conditions in pregnancy. In: James DK, Steer PJ, Weiner CP, Govik B, eds. High Risk pregnancy, management options. $2^{\text {nd }}$ ed. London: WB Saunders; 1999:559-598.

3. Nath G, Chaudhary M, Prakash J, Pandey LK, Singh TB, Jai P. Urinary tract infection during pregnancy and fetal outcome. Indian $\mathbf{J}$ Med Microbiol. 1996;14:158-60.

4. Chandel LR, Kanga A, Thakur K, Mokta KK, Sood A, Chauhan S. Prevalence of Pregnancy Associated Bacteriuria: A study done in a tertiary care Hospital. J Obstet Gynecol India. 2012;62:511-4.

5. Hankins GD, Whalley PJ. Acute urinary tract infections in pregnancy. Clin Obstet Gynaecol. 1985;28:266-78.

6. Khatun AK, Rashid H, Chowdhury TA. Prevalence of urinary tract infection in pregnancy. J Bangladesh Coll Phys Surg. 1985;2:6-10.

7. Nicolle LE. Asymptomatic bacteriuria: when to screen and when to treat. Infect Dis Clin North Am. 2203; 17:367-94.

8. Stenqvist K, Dahlén-Nilsson I, Lidin-Janson G, Lincoln K, Odén A, Rignell S, et al. Bacteriuria in pregnancy. Frequency and risk of acquisition. Am J Epidemiol. 1989;129:372-9.

9. Girishbabu RJ, Srikrishna R, Ramesh ST. Asymptomatic bacteriuria in pregnancy. Int $\mathrm{J}$ Biol Med Res. 2011;2:740-2.

10. US Preventive Services Task Force. Screening for asymptomatic bacteriuria. In: Guide to clinical preventive services. $2^{\text {nd }}$ ed; 1996.

11. Gayathree I, Shetty S, Deshpande SR, Venkatesh DT. Screening for asymptomatic bacteriuria in pregnancy. An evaluation of various screening tests in Hassan District Hospital, India. JCDR. 2010;4:2702-6.

12. Patterson TF, Andriole VT. Bacteriuria in pregnancy. Infect Dis Clin North Am. 1987;1:807-22.

13. Cowan and Steels manual for the identification of medical bacteria. In: Barrow GI, Feltham RKA, eds. $3^{\text {rd }}$ ed. Cambridge: Cambridge University Press; 1993.

14. Rubenstein JN, Schaeffer AJ. Managing complicated urinary tract infections: The urologic view. Infect Dis Clin North Am. 2003;17:333-51.

15. Hooton TM, Stamm WE. Diagnosis and treatment of uncomplicated urinary tract infection Infect Dis Clin North Am. 1997;11:551-82.

16. Chukwu OS, Ezeonu IM, Victor MA, Moses NA, Uchenna UG, Owolabi JO, et al. Incidence, aetiology and antibiotic susceptibility profile of asymptomatic bacteriuria in pregnant women in Nsukka Urban, Enugu State, Nigeria. World J Life Sci Med Res. 2014;3(3):94. 
17. Kasinathan A, Thirumal P. Prevalence of asymptomatic bacteriuria in antenatal women attending a tertiary care hospital. Int $\mathrm{J}$ Reprod Contracept Obstet Gynecol. 2014;3:437-41.

18. Lallar M, Haq A, Nandal R. Asymptomatic bacteriuria: predisposing factors and correlation with preterm labor in low resource settings. Int J Reprod Contracept Obstet Gynecol. 2014;3:403-8.

19. Kerure SB, Surpur R, Sagarad SS, Hegadi S. Asymptomatic bacteriuria among pregnant women. Int J Reprod Contracept Obstet Gynecol. 2013;2:213-6.

20. Tadesse E, Teshome M, Merid Y, Kibret B, Shimelis T. Asymptomatic urinary tract infection among pregnant women attending the antenatal clinic of Hawassa Referral Hospital, Southern Ethiopia. BMC Research Notes. 2014;7:155.

21. Ansari HQ, Rajkumari A. Prevalence of asymptomatic bacteriuria and associated risk factors among antenatal patients attending a tertiary care hospital. J Med All Sci. 2011;1(2):74-8.

22. Vaishali J, Anjoo A, Vinita D. Asymptomatic bacteriuria during pregnancy-health professional's perspective. J Obstet Gynecol India. 2009;59(5):4403.

23. Asopa J, Dadhich Y, Mathur SA. Prevalence of asymptomatic bacteriuria among antenatal women and identification of bacteria in urine. Int $\mathbf{J}$ Renal Dis. 2016;1(1):01-5.

Cite this article as: Narang $\mathrm{R}$, Nandmer GK.

Asymptomatic bacteriuria in antenatal cases and its effects on obstetrical outcome. Int J Reprod

Contracept Obstet Gynecol 2019;8:853-7. 